\title{
Hour Times Milligram Per Milliliter Per Milligram Per Kilogram
}

National Cancer Institute

\section{Source}

National Cancer Institute. Hour Times Milligram Per Milliliter Per Milligram Per Kilogram.

NCI Thesaurus. Code C105468.

A dose calculation unit expressed in hours times milligrams per milliliter, divided by milligram per kilogram. 